\title{
Anthrovision
}

Vaneasa Online Journal

Vol. 7.2 | 2019

Epistemic Disobedience

\section{Never Silent Sights.}

De(colonial) Affect in a Social Environment of Racialisation.

\section{Thomas John}

\section{(2) OpenEdition \\ Journals}

Electronic version

URL: http://journals.openedition.org/anthrovision/5821

DOI: 10.4000/anthrovision.5821

ISSN: 2198-6754

Publisher

VANEASA - Visual Anthropology Network of European Association of Social Anthropologists

Electronic reference

Thomas John, "Never Silent Sights.", Anthrovision [Online], Vol. 7.2 | 2019, Online since 10 November 2020, connection on 26 January 2021. URL: http://journals.openedition.org/anthrovision/5821 ; DOI: https://doi.org/10.4000/anthrovision.5821

This text was automatically generated on 26 January 2021 .

(c) Anthrovision 


\section{Never Silent Sights.}

De(colonial) Affect in a Social Environment of Racialisation.

Thomas John

\section{Introduction: Indigenous Artist Invites German Visual Anthropologist to Nude Photoshoot}

1 If the headline above sounds a bit like a tabloid press style, it did its job well. But during my last fieldwork trip to South-Mexico one of my research interlocutors from the local ethnic art and media scene did actually invite me to take part in a nude photoshoot and I accepted. In the following article I reflect on some of my experiences and "experiments" in the context of working as a visual and media anthropologist in Chiapas (South-Mexico).

2 I assume that many human encounters and events might be an experiment, in the sense that we take part in an event, or in an interaction not yet familiar to us. The inter-human experience might produce a "reaction" and we learn from that. Thereby, a new affective and emotional relation might be an outcome to come into play. The new experience might transform or impact us. Sometimes we might take a risk, or try out something unconventional for us, as Xun and I did, when we took part in a photoshoot for Juan. How is that related to Mignolo's (2010) "epistemic disobedience"? I will discuss some of these personal experiences in the context of my media-ethnographic fieldwork observations and debate these in relation to some selected perspectives from the cultural affect studies (Gregg and Seigworth 2010, Slaby and Röttger-Rössler 2018).

To begin with, I share two photos with you, without yet theorizing about them too much, to exploit their potential as visual representations. They might evoke emotions and reflections on part of the spectator that are different from responses to academic texts, and rather generate intuitive affective notions and knowledge (MacDougall 1998). Both photos show the same person, Xun Betan, taking a selfie with another naked person. On the left side you see a selfie in the narrow sense, while on the right side you see a photo depicting the moment of a selfie being taken. After you look at these 
photos, I will introduce my research field and its ethnographic context, before elaborating on the photos in more detail.

Fig. 1: Juxtaposition of two photos

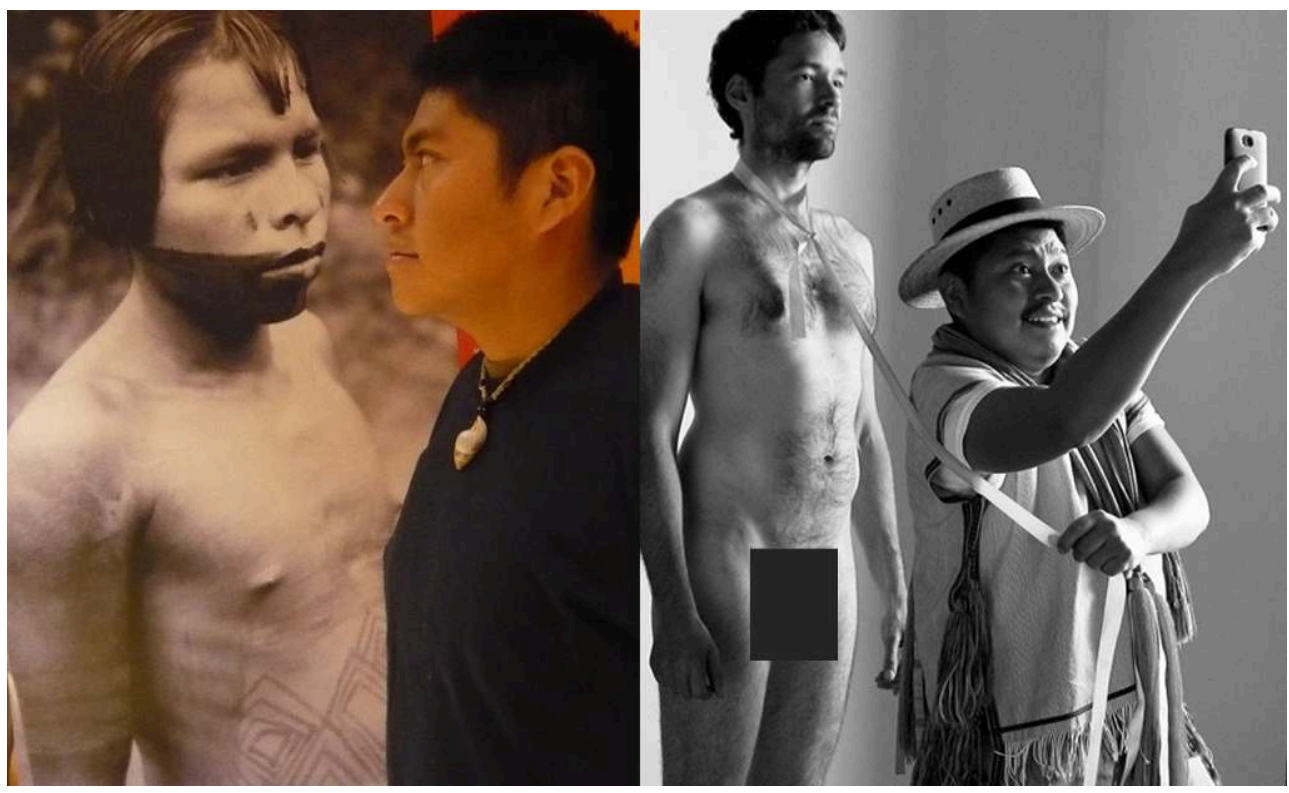

Left: Selfie shot by Xun Betan 2013. Right: Xun Betan in the moment of a selfie shooting, photographed by Juan Chawuk 2017.

Photos by Xun Betan (left) and Juan Chawuk (right)

\section{Researching Local Media Productions and Media Practices as Affective Negotiations}

4 The paper at hand has a strong relation to my research project, that is concerned with a local network of indigenous independent filmmakers and photographers in South Mexico. I am interested in the affective negotiations of feelings of belonging (Acker et al 2019) and debates about the concept of indigeneity in the context of my social actors' film-productions, biographies, and media practices. Deriving from practice theory, the latter are all kinds of interactions concerned with a medium, such as the production process or the circulation and reception of a film or photo, but also for instance a private conversation among filmmakers or between filmmakers and friends, family members, or funding institutions, or any kind of action and event in the day-to-day life of my social actors that relate to a medium. Working with "media practices" (Couldry 2010) applies for me to both method and theory (Kummels and John 2019, John 2016) as I use my data to elaborate how local media producers are doing media practices to affect people and to negotiate the "affective atmosphere" (Riedel 2019) of their social environment and region, to impact or transform the subjective affective relationships of people to politics of indigeneity and ethnic belonging within the nation state ${ }^{1}$.

5 An affective atmosphere is subjective and relational. One and the same place, human encounter, or situation might feel charged with a different atmosphere depending on a person's perception. From cultural and anthropological affect study perspectives, affects and an affective atmosphere cannot be observed directly, but rather what we 
can grasp are the social effects of an affective relation. We can observe how people relate to affect through their behaviour and practices, and we can listen to people how they talk about, express, and react to being affected (Skoggard and Waterston 2015).

\section{(De-)colonial Affect: Living and Intervening in an Environment of Structural Discrimination}

6 The social actors of my research are people who moved from ethnic communities to the rural metropolis San Cristóbal de las Casas. In the city, they experience marginalisation and racialisation at many different levels. The city is the site of the former colonial regional capital. It has been and still is dominated strongly by the Ladino society, even though people from ethnic communities have outnumbered the Ladinos for a few decades, after a massive and ongoing migration to the city. Several of the local media producers pointed out to me that if you consider Mexico, its politics, and its Ladino society as racist, then San Cristóbal de las Casas would be just a "super racist" setting.

7 The local art and media producers commute regularly from San Cristóbal de las Casas to their communities of origin. Some of them were born in the city as children of migrants from rural communities. These people, like thousands of others, belong both to the city and to ethnic communities at the same time. The ethnic communities established themselves in new forms in the city too, after new multi-ethnical neighbourhoods were established on the outskirts of the city. The Ladino population considers the city as "their" city. The transformation of this small countryside metropolis had not been a very harmonious process in the 90s when migration intensified. While the Ladinos saw that process as an "invasion", the indigenous migrants who were driven out of the rural areas by economic and demographic pressures "were compelled to develop extraordinarily coherent, militant forms of organization first to push their way into the city and acquire land, and then to secure urban services and eventually political representation and a share of power" (Rus and Escamilla 2015: 81).

8 In the city and its surrounding local districts where I conducted my research, there is a very particular "affective economy" of a racialised divide. The Ladinos (called "Mestizos" in the Mexican context) who have the political power look as "whitened elites" (Berg \& Ramos Zayas 2015) somewhat down on the people from ethnic communities. My interlocutors have shared with me many of those experiences of structural and inter-human discrimination they have to deal with in their daily life, and described the city as an environment of institutional and structural discrimination. They also talked about how this affects the city's atmosphere for them and their emotional relation to the city, its institutions, and its public, and how this motivates and impacts on their media productions.

9 Among other categories, people I engaged with are categorized in the national Mexican context and its Ladino majority society as "Indígenas" (indigenous) or as "Indios" (Indian). Indio is a term that is used in Mexico mostly in a dismissive and discriminatory manner. However, the word "indigenous", which is widely used in the academic literature, in the local context of art and media producers in Chiapas is a highly contested term, which some of them have appropriated to refer to themselves, whereas others critique its usage. In order to gain access to specific funding or other spaces of "indigenous media" productions, they also need to identify themselves and 
their media strategically as "indigenous". Many of them argue that "indigenous" is an imposed term, and that still bears prejudices and is fostering dynamics of othering, stereotyping, exoticisation, and racialisation of national ethnic minorities. While defending different perspectives, the very issue of debating, situating, and reflecting the term "indigenous", is a matter which all of my interlocutors from the local art and media network brought up at some stage in our conversations. In fact, many of them also refer to themselves as "indigenous producers" while being cautious with the term at the same time. Many argued that it depends on the context of usage - of whom and how the term is being used ${ }^{2}$.

10 For the local producers, media production is among other things a means of intervention to negotiate the "image" of people from ethnic communities, and to challenge external images and (visual) knowledge production about them. The filmmaker María Dolores Arias Martínez told me her thoughts on the representation of indigenous people and on the role of the local media network. I quote her at length, since her statements express the colonial relation between indigenous people and images of them very well, but she also articulates the decolonizing affective mood that "own" media productions can generate and disseminate:

I think that local [media] production is really important to crush stereotypes, because certainly there are stereotypes about us and the indigenous communities. We know that. It is what we have seen in television, in soap operas and films: always it is the "Indigenous", the "Indio", who does not know how to talk correctly, who doesn't know to... who walks and moves different, who looks different, dresses up different, who is moreover totally dirty. This is the common image of the 'Indigenous'. The indigenous women on television are always something...like for example servants, like this we see them on television, and in films, that is the stereotype! And it is very strong.

Then, let us say the first closer encounters that the communities had with the audio-visual has been through the anthropologists who have been bringing their cameras and they have been filming and doing photos, and they interpreted those events and everything they saw and recorded, but that is a particular interpretation of specific events that happened at some certain moment, and they captured it and they took those images with them and those images never returned, and that is the complaint we have, no? [...]

How do you call a character or a person you investigate? One calls them the "Other", "oh, let's go to investigate the Other" - but now, I am the Other, yes, I am the Other myself, so how will I refer to this Other if I am the Other, because now it is not any more somebody else who comes to point a camera at us, but now I take the camera myself to film my people. This is the great difference, that now, not necessarily someone from elsewhere comes and speaks and interprets and records, but now we are doing it and we started to be conscious about what aspects we want to show and which things we do not want to portray. No longer we want to show dirty faces, poor barefoot people, no longer we want to show that, because this image has damaged us, this generated prejudices against us, no? Well, no longer... Now, we want to represent other things, we want to re-appreciate our communities through the image, and I believe one can see that in our works, well, at least we are trying to achieve that.

(María Dolores Arias Martínez, interviewed by Thomas John 2017, author's translation)

11 María explains here how she sees her people in an asymmetrical power-relation regarding visual media produced by television, filmmakers, and anthropologists, and how she and her local producers' movement are intervening in the affective "visual economy" (Poole 1997) of images and media representations by producing their own media about themselves. Images and other media can generate, represent and disseminate political emotions and affect (Ahmed 2004, Bens, Diefenbach and John et al 
2019). In conflict with the racist social environment, the local media producers and productions generate within their networks and through their practices an affective atmosphere of resistance, pride and appreciation of ethnic belonging. Their concern is that they see that many people feel ashamed of their origins, and they narrated in our conversations how they experienced such painful feelings of shame themselves.

\section{Xun Shoots a Selfie With a "Native"}

Fig. 2: Title of the photo: "Las miradas no callaran" (Never silent sights)

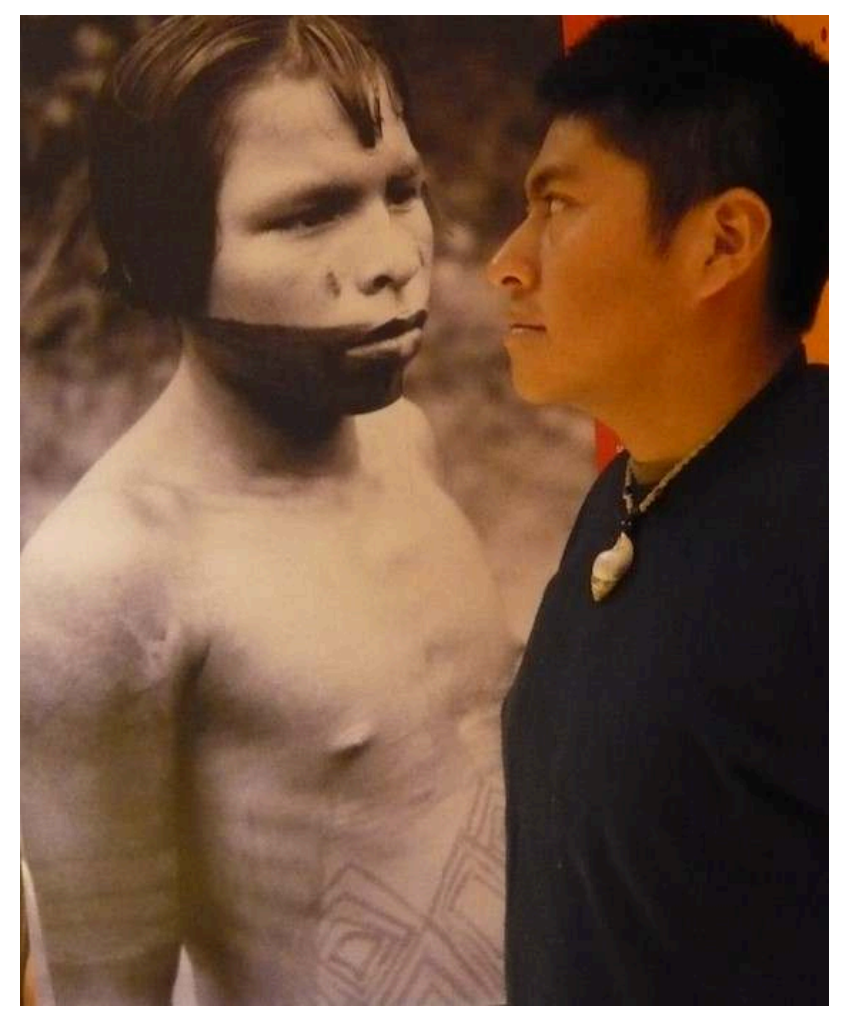

Photo by Xun Betan 2013 
Fig. 3: Xun Betan takes a selfie with Thomas John

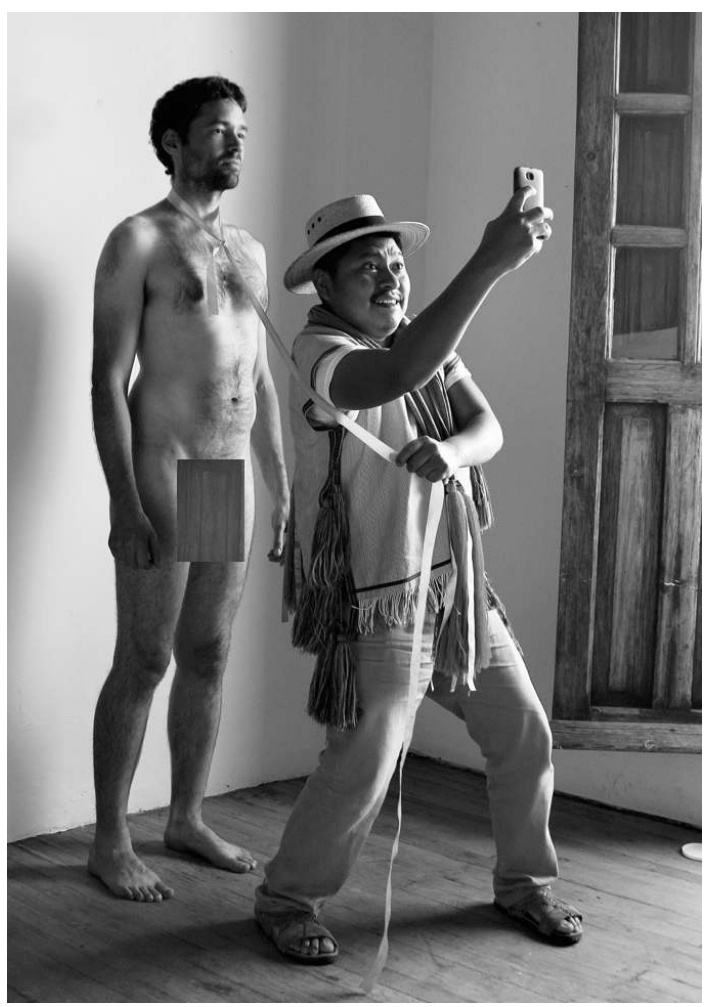

Photo by Juan Chawuk 2017.

12 The selfie (Fig. 2) really struck me emotionally when I saw it for the first time, and it still does. Xun took it the Museo del Oro in Bogotá, where old archive photos of Columbian "Natives" have been exhibited in life-sized prints. This print was in a section entitled "Kuna people". In that selfie, Xun placed himself not with his back to the person, as he did while photographing himself with me (Fig. 3), but at eye-level and at an angle, so that his photo creates the sensation as if Xun was looking into the eyes of the photographed person, as if receiving and answering the gaze of that person. I believe, that there is more behind that play of perspective and angle. Xun received the virtual photographic gaze from a black and white photo, and thereby interacted with a person and a colonial history deeply interwoven with his own identity in the contemporary Mexican nation-state too. He published the photo on Facebook with the heading "Del Sur, Centro y Norte, somos del mismo pueblo, Pueblos Originarios..." (In the South, Centre and North, we are from the same community, the indigenous communities...).

13 I think this selfie bears a strong meaning. I feel that Xun receives the empty and anonymous gaze of the young nameless man on the photo, who the museum spectator would know only as a Kuna person. Xun's photo is an act of emotional recognition. Did the young man know that he had been photographed? Did he give his consent? Did he ever see this photo, or any photo of himself? He must have been dead or yet very old by the time of the exhibit, when Xun took his selfie with him. How would that person feel, knowing that he is exhibited in a museum? Would he feel proud, or awkward? We will never know the answers. How would he feel seeing Xun's selfie? Xun had for sure no consent by the photo subject to take his photo. This is a tricky issue regarding ethics. However, I felt that by receiving and contesting with a very firm look the gaze of the 
young man, and by representing at his selfie that very moment of interaction with that unknown identity, Xun did somehow do justice to that anonymous person. He acknowledged him as a human who deserves to be met at eye-level. Xun tried to decolonize the image by this intervention and by creating a photographic representation disseminated on Facebook.

There are many portrait photos in which people are captured looking straight into the camera's lens and which creates the feeling as if they would look right into our eyes. The photo in the museum and its subject is an image you would look at. It was not supposed to be an image that looks back at you. However, Xun allowed the image and its subject to look at him too, symbolically transforming the subject of the photo into a meaningful protagonist and an agent. It is true that we are not really aware of the context and moment of the original photo, nor of the relation between the photographer and the subject. However, what matters more for now is what Xun made out if it, through this very conscious act of remediating (Deger 2016, Bolter and Grusin 2000) the original image through his selfie. Speaking with Xun about this selfie in more detail, and getting to know his wider perspectives on coloniality and decolonialisation during many conversations, I learned that my own feelings and interpretations of the image were not far-fetched. He supported my interpretation and my feelings.

In the context of a decolonial Epistemic Disobedience (Mignolo 2010), I would like to draw attention to the matter that Xun remediated a photo in a way that altered clearly the intention of the original photographer, and also probably the intention of the exhibiting institution, a national museum. He transformed the encoded notion of somebody to be looked at, a "Native", into somebody who is looking back at you. Xun disobeys the intended purpose of the photo. He subverts and decolonizes an ascribed power-relation and the potentially ascribed intention for decoding the image. His comment on Facebook adds a transcultural and pan-American notion to his selfie, identifying himself and expressing solidarity with the subject and speaking out in plural, to belong to the Pueblos Originarios of South, Central or North America.

\section{Xun Shoots Selfies With Another "Native"}

While we had been doing the nude photoshoot in 2017, I had not been thinking of that selfie photo by Xun (Fig. 2). The event happened very spontaneously. Today, I see a very strong relation between these images, or, to be more precise, I would like to draw a relation. Fig. 3 is a scene of a spontaneous role-play performance lasting for about 15 minutes. It was photographed and initiated by the local artist Juan Chawuk. He is an internationally acclaimed painter who expanded his art practice in the past few years to sculpture, performance, and lately also photography. Juan Chawuk is originally from a Tojolabal-speaking community of the region of Las Margaritas in Chiapas, from which he migrated to San Cristóbal de las Casas. As a Tojolabal, he is a Mayan-descended person, like Xun, who is a Tsotsil.

In the photo above you can observe how Xun takes a selfie with me. He placed himself in front of me, as if I was a statue or an object. I have a frozen face, and I do not smile into the camera, while Xun performs a facial expression as if he would photograph himself in front of an attraction, a curiosity, anything really worth or interesting having a photo with. He seems to be in motion, while I am standing very still and straight. His knees are slightly bent and it seems as if he just jumped in an aroused 
mood in front of me quickly to take that selfie. Around my neck is a strap, the only thing I am wearing on my naked body. It is not an iron chain but, especially since Xun is holding the other end of the strap in his hands, it evokes clearly the assumption, that he has the power, while I am captured without agency of my own and definitely under his control. He is dressed nicely and is wearing ethnic traditional dress.

Fig. 4: Xun takes further selfies with Thomas

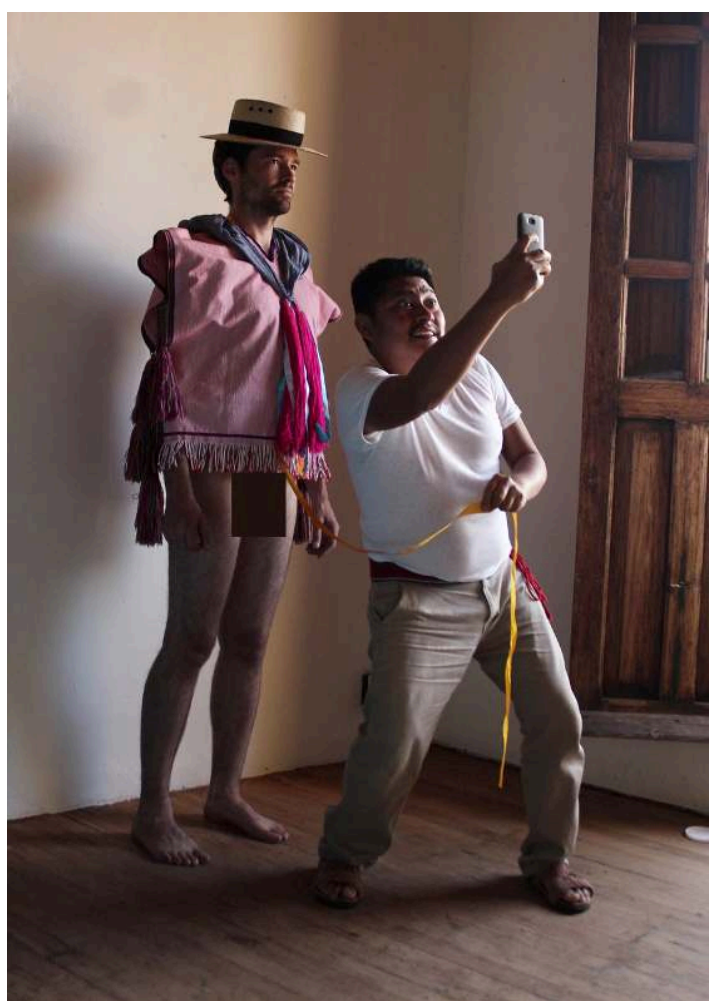

Photo by Juan Chawuk 2017. 
Figures 5, 6, 7, 8: Xun takes further selfies with Thomas
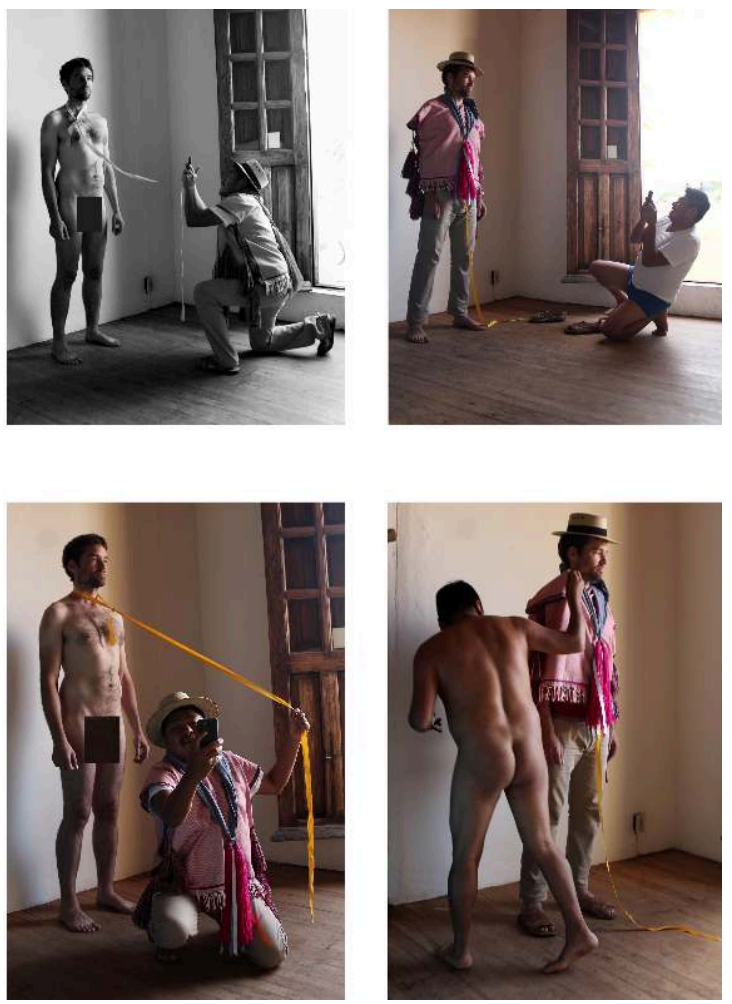

Photos by Juan Chawuk 2017.

18 As local artists, Xun and Juan and their art products, especially their photographic works, have been my research focus. Both of them have become used to being filmed by me, especially Xun. As a visual anthropologist, I took photos and shot videos of them. I use video and photography as a research tool to produce empirical data, but sometimes I produce images also to create documentary representations, which I publish or use for academic presentations. For example, I produced a three-channel video-installation for which Xun worked with me in front of my camera as the main protagonist (see photos below). 
Figures 9, 10, 11, 12, 13: Video installation entitled Never silent sights.
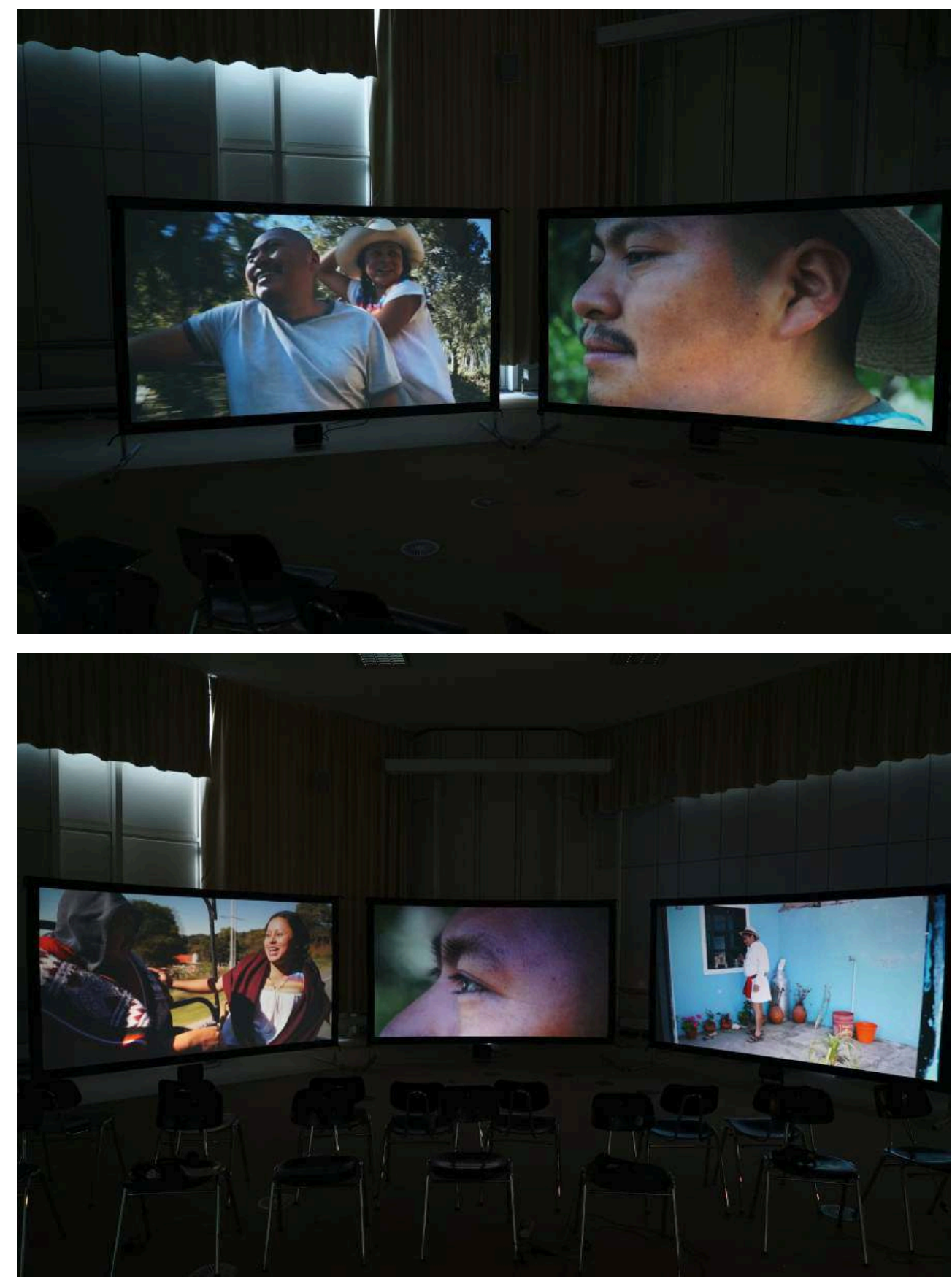

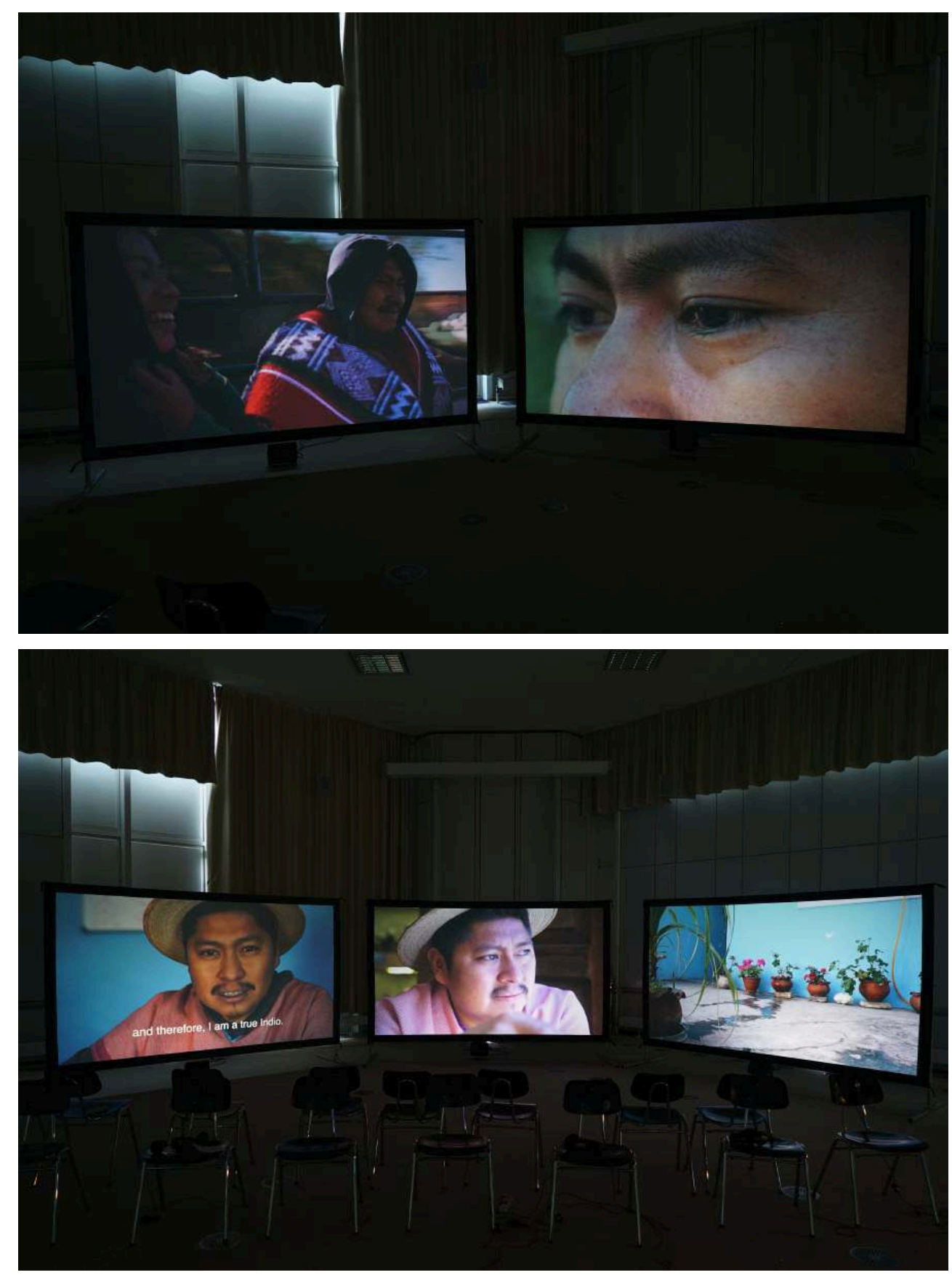


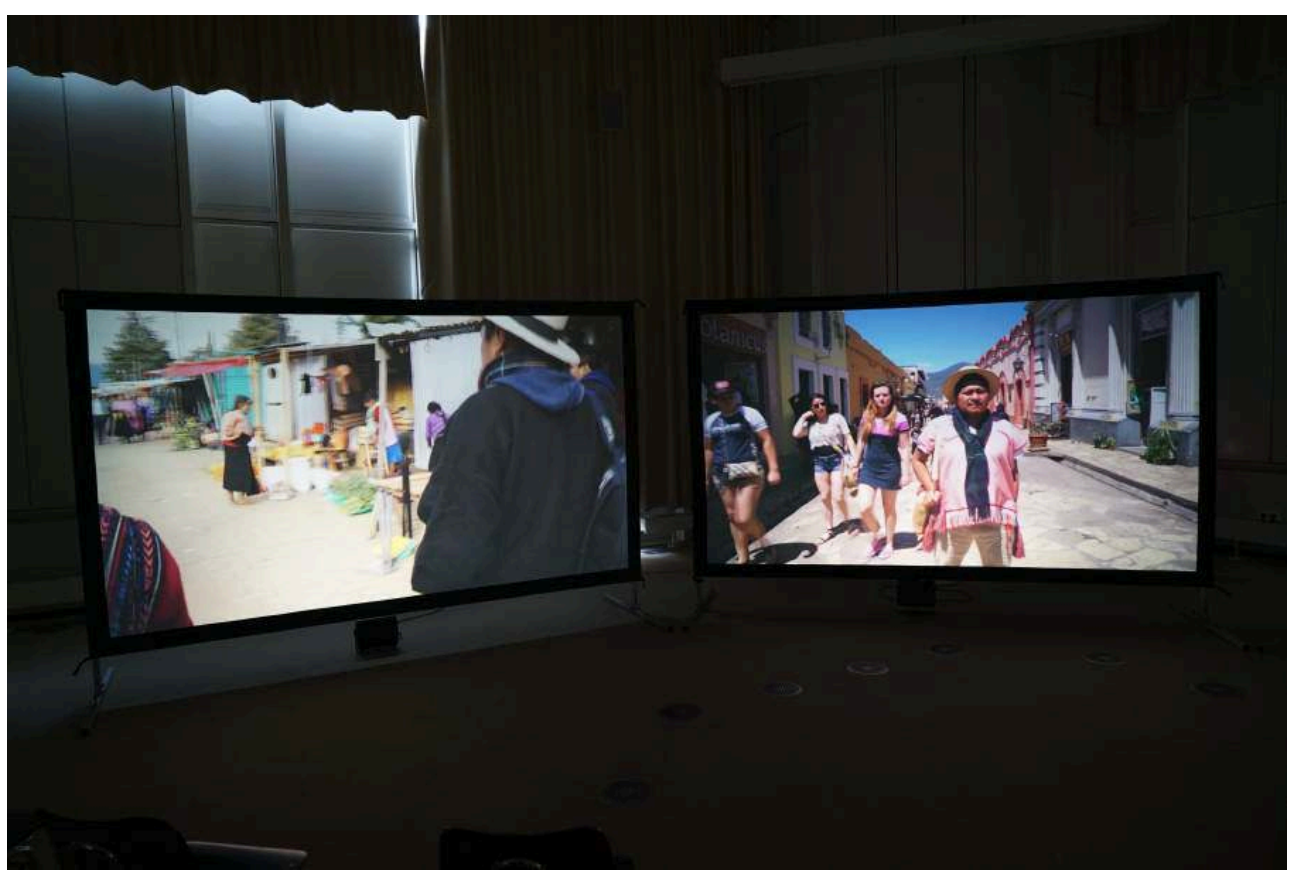

The installation was exhibited at the German Anthropological Association's conference in Berlin 2017 in a show-room for visual anthropological exhibits and installations.

Photos by Thomas John 2017.

In the case of Juan, I have not been shooting video to edit a documentary work to exhibit and screen it, but primarily to create empirical records as data for my research. I recorded interview video clips of him showing me his photographs, sculptures, paintings, and web pages, which represent his works, while he explained and contextualized them for me. This is a simple form of elicitation and empirical record for me, and at the same time, my video footage helps me while analysing my data, to get a feeling for moods and emotions that have been expressed in the conversations, or while my conversation partners have been showing me photos, videos or web pages.

However, this time it was my turn to be in front of the camera. Since Xun and Juan are well acquainted with each other, we met to have lunch together, and Juan asked us if we would do a nude photoshoot for him. He explained to us that he was doing a new photographic project for which he always asks two people to be photographed naked in pairs. The basic idea would be that those two people interact somehow with each other in front of his camera, but that Juan would take photos without interfering or directing. He explained that he has done already a few of those photoshoots, and could easily imagine Xun and me as one pair participating in this undertaking. Furthermore, he informed us that he was still unsure about what to do with the images. He could imagine doing an exhibition, but he might use the photos only as a personal resource and an inspiration for his painting and sculpturing practices.

21 For my part, I didn't have a problem with that. I felt comfortable and trusted Juan and Xun. I felt that I didn't have an issue with nudity in that context of an art production. Xun hesitated a bit, and said that he felt unsure, since he might feel ashamed of being naked. However, he said he would like to try. Moreover, he asked if he could also be dressed, or not completely naked, while only I would be naked. Juan said that would not be a problem for him, as long as there was nakedness and two people. He said that it could be interesting too, if only the güero (Mexican slang for "white guy") would be 
naked. Spontaneously, we went to Juan's studio which was nearby, and we joked about how I could be the naked "native primitive German dude", or "the naked anthropologist", while Xun would be the nicely dressed "civilized" Tsotsil person. Xun seemed to like that idea, and we got into it. He was wearing traditional Tsotsil dress that day, as he usually does. Sometimes he wears the traditional dress of his community, which one would usually do, if wearing traditional dress at all. In the city especially, wearing such dress might reinforce experiences of marginalization. However, Xun also wears outfits from other Tsotsil communities or totally different ethnic societies. This is something special about him. He owns about 15 different ethnic outfits, even though he favours regional dresses to wear them in public. On that particular day he was wearing dress from Zinacantán, which is a Tsotsil community, too, but not his own original community, as he comes from the region of Venustiano Carranza.

We agreed spontaneously that we would try out that game of performing an encounter between a "native güero" (white guy) and a "civilized" Tsotsil guy. We agreed that I would not talk and not move, but that I would stand still and only react to what Xun demanded. He started to observe me, and he looked closely at different parts of my body, as if I were an uncommon person or a curiosity. He found a belt made of yellow fabric in the studio, which he tied around my neck. He curiously touched different parts of my body, at times a little bit rudely, pushing me around. He turned my head, or grabbed my hair and pulled my head down to his eye level to look at it closely. We did not talk at all until the end of the role-play, and Xun just did what he wanted with me. He took out his mobile phone and started to take pictures of different details of my body, then he pushed me around a bit again, to put me in different positions to take photos of me, and then he started to take selfies with me. Finally, he started to undress himself bit by bit. First, he took his hat off to put it on my head and to take a photo of me remaining naked but with a hat. Then he took off his Zinacantecan dress to put it on me, but he did not bother to put it on nicely. He just slipped it over me, without putting my arms through the armholes. He took further photos of me still without pants, but with his hat and his dress. He looked at me in a very pleased and happy way and took more selfies with me. Meanwhile I stood there a bit grotesquely, with my arms under the dress as if wearing a straitjacket, half naked and like a strange display dummy. Xun continued to put his clothes on me bit by bit, and finally also his pants and sandals. He acted as if he was highly satisfied with the result, looking at me as if he had achieved a success. A bizarre role reversal took place, when finally he got completely naked and took more selfies with me. He was smiling into the camera and acting as the "naked native" next to me dressed in the Tsotsil "straitjacket" outfit.

The obvious interpretation of this role-play is that Xun looked at an "exotic white native" which he found curious. He "civilised" him by putting his own clothes on the stranger, trying to make the stranger equal with himself. However, he did that halfheartedly without seriously trying to transform the other, instead mocking him by leaving him with a weird appearance. He dominated the stranger, ridiculing me, and he took his photos and selfies without asking for permission, well, without speaking at all with me. He put the strap around the stranger's neck as a symbol of an asymmetrical power relation.

Thomas, the white visual anthropologist who would usually take photos and videos of "social actors who experience marginalisation and racialisation", and who "get categorized in the national Mexican context as Indígenas or as Indios", (as he described 
his research interlocutors earlier in the present article), is represented through the role-play in a marginalised and racialised position, becoming a fetishized and objectified exotic subject for Xun and Juan. The role-play and its photographic representation subvert assumed and ascribed power relations. In what kind of power relation had I really been with Xun and with Juan? What power relation would people ascribe to us, independently of our personal inter-human emotional relationships? And how might such ascriptions from a third person impact on our feelings and the intersubjective atmosphere with each other? Did the photoshoot have any consequences for us, and did it alter sustainably our affective perception or relation regarding issues of ideologically and socially ascribed racial differences between us? Honestly, I can provide only tentative answers to most of these questions, but I think it is important to ask these questions anyway.

The photos and the photoshoot itself are meaningful in various ways, for instance by provoking reflections on images, photography, and visual (mis)representation. Misrepresentation is a locally very frequently debated issue and people are very sensitive about it. People feel hurt and stereotyped through photos and videos taken by outsiders, (remember also the related longer statement about misrepresentation and "own" media by the local filmmaker María Dolores provided a few pages above.)

26 I believe that the matter is more complex than the obvious access of interpretation along the historically constructed dichotomy white guy vs. indigenous guy and the acting out of colonial history. Beyond that, I would like to relate that photoshoot to certain fieldwork experiences and to narratives of my research interlocutors, to show how the photoshoot might be seen as a small intervention in a complex affective relationship between humans and their embeddedness in history, politics, and their actual social environment. For the time being, this event was an intervention in the microcosm of the three of us who had been involved. However, through the possible circulation and exhibition of these photos, and other works by Juan which I will show and discuss, a dissemination of a political affect (Bens, Diefenbach, John et al 2019, Ahmed 2004) and a decolonial emotional reflection might be stimulated.

Our role-play was not planned conceptually beforehand, but was performed in a spontaneous mood and without a clearly communicated intention or aim. Nevertheless, the medium of photography helped us to represent and to practice transculturally a critical notion of coloniality beyond a spoken or written debate. That might affect the spectator at an intuitive level (MacDougall 1998) and provoke a feeling or emotional reflection on (de)colonialism and our own relation to that. The photos represent symbolically colonialism but also empowerment and a decolonizing moment.

Is our role-play relevant? Did we decolonize anything by acting out the colonisation of me and my body? That I collaborated in the photoshoot was not a great sacrifice on my part, and honestly it also contributed to my fieldwork and thereby to my own ends as well. Nevertheless, it shows that I was willing also to be in front of a camera, while there had been enough other moments when Xun and Juan had been recorded by me with my camera. Further, it demonstrates to Xun and Juan, that I have been willing to collaborate also on my part in the greater project of local cultural activists and artists such as Xun and Juan, to generate awareness and to articulate their critical perspectives within an affective racialised economy (Berg and Ramos Zayas 2015) ${ }^{3}$ in which relations between ethnic communities and the nation state with its "whitened elites" of the Ladino society are acted out. Does the fact that I have been naked add 
anything to all of that? The nakedness might be understood as a symbolic act of addressing power-relations and racialisations that are still at work, and it points to the history of representation of (naked) indigenous "Others". The central role of photos and selfies in this event relates to colonial and racializing images that have been depicting indigenous people until to date.

Even though I tried to partake in the greater anti-hegemonic and decolonising activist project of local producers like Juan, that does not mean that I did highly collaborative research at each and every time of my fieldwork. Nevertheless, I believe that I have gone "beyond participant observation" (Rappaport 2008) to be the naked subject of a photoshoot in which a historically generated and ascribed power relation has been evoked and subverted is important, if only for the three of us involved. I would not label this event in a pretentious manner as a great decolonial practice, but would rather speak about it more modestly as an attempt to explore "decolonial options" (Mignolo and Escobar 2013).

\section{Shared Experience of Ascribed Power-relations}

30 I would like to relate our role-play to some witnessed events and narratives of my interlocutors. Together with Xun, Juan, and other media producers, I experienced diverse moments of stereotyping and racism in the city. Interestingly, many of these were moments of an internalised racism, which means that people themselves considered as "indigenous" did for instance discriminate against Xun and Juan, through relating them in some sense as subordinate to me. In the case of my experience with Juan, it happened in a restaurant: After I visited him at his home to interview him in March 2017, we went to a nearby restaurant to have lunch. That day I totally forgot to take enough money with me, and I excused myself saying that he would have to pay for me on that occasion, since I had almost no money on me. After our lunch, Juan asked for the bill but the waiter put the bill in front on me. Without even looking at the bill, Juan took out a 500 Peso banknote (a week's salary for a waiter working at a simple restaurant) and gave it to the surprised waiter. After we left the place Juan brought up the topic and said: "Did you notice? The waiter treated me like a "poor Indio", even though he himself is indigenous!"

31 The conversation continued and Juan told me about how even indigenous people would marginalize him as inferior to his company, as soon as he is in the company of Ladinos or foreigners.

32 I also experienced a similar situation with Xun in spring 2017. We had been at the local market of San Cristóbal de las Casas, where people mainly from the ethnic communities sell their goods and foodstuffs. Xun proposed to film some footage of him moving around that environment, since we were then working on the previously mentioned installation Never silent sights (see also figures 9-13 above). He recited one of his poems at the market, and I video recorded him. A fruit saleswoman from whom we had bought some fruit earlier had been watching us. She came over and talked with Xun in Tsotsil. I felt that they were talking about me, and Xun pointed at me. They saleswoman seemed to be highly surprised. As we went on to stroll around the market, I asked him what they had been talking about. He said that the woman was curious, is he working for the white guy, and what kind of work is that? He answered her, saying that he was not working for the white guy, but that I was working for him as his assistant, to produce a 
film about San Cristóbal de las Casas and its markets. This incident did not really surprise me. Xun had played a trick on the saleswoman. He was not producing a film about the market. However, he was also not really joking with the saleswoman, but he had a point to make. He certainly impressed his counterpart. Xun is very sensitive to detect internalised racism, and he often takes a radical position.

In both cases, at the restaurant with Juan and at the local market with Xun, the waiter and the saleswoman discriminated against Juan and Xun most likely unconsciously, and not intending to be mean. However, there are also other forms of (internalised) racism happening, which are really meant to be mean. Xun and Juan are people who want to change this affective colonial atmosphere of racism and subordination of people from ethnic communities.

The courage and resistance of Xun and Juan cannot be taken for granted. Xun has been telling me that he had been feeling really ashamed of his indigenous origin throughout his childhood and youth, because he was bullied at school by Ladino teachers and classmates. I recorded an interview in which Xun told me how he himself discriminated against his own mother when he was young. He felt ashamed of her walking in traditional dress next to him and talking Tsotsil to him in public, and he asked her to stop talking, and kept some physical distance from her when classmates were passing by, which really hurt his mother. He explained how this could happen and told me that in his school, a teacher named Bartolome made him sweep the floor of the classroom in front of all his classmates. Xun had scored a better result in an exam than the son of Bartolome. This had really upset the teacher, and he shouted at his own son that this cannot be, that an "Indio" scored a better exam than him, while "Indians" are supposed to be only good for work such as sweeping the floor, and he gave a broom to Xun, and told him to sweep the classroom in front of his classmates.

This is just one story about many such experiences that people like Xun grew up with. Xun wrote a short essay about that experience in school and published a poem along with the essay which he dedicated to his aforementioned school teacher. The poem deals with discrimination but also with pride and empowerment over discrimination.

Nevertheless, after a period of negation of his Tsotsil background in his youth, since his early 20s Xun has experienced a transformation of his feelings of affective ethnic belonging, and he has started to become aware of the history and the contemporary mechanisms of racialisation, which many people such as him are exposed to in Mexico. He started to feel that he does not want to try anymore to assimilate and belong to the majority Ladino society, but that he will defend himself as being different. Nowadays, in his mid 30s, he is one of the local subaltern intellectuals in town being very active against racism and demanding a pluricultural society in which cultural differences are acknowledged.

These two experiences at the restaurant with Juan and the market with Xun, and also the brief insight into Xun's biography, exemplify that our role-play and photoshoot is entangled with a social reality in Mexico and potentially also beyond Mexico. Independently from our personal relationships, we are placed in a racialised powerrelation by people. That does not feel right to us. It might sound weird or might be risky to say that from my supposedly privileged position in this social constellation, but I feel discriminated or labelled and homogeneized in such moments too. Our role-play, the photoshoot, and also Xun's selfie in the museum disobey and question an ascribed racial power relation that is often taken for granted. 


\section{Pakal Decolonized: Juan Chawuk's Sculpture and Photo Project "Pakal"}

In the following, I turn to another performative photographic project by Juan Chawuk. Again, a naked and (de-)colonised image is central to this work, and again, collaborative and transcultural moments are the driving elements.

Figures 14, 15, 16: Stills from my video-interviews
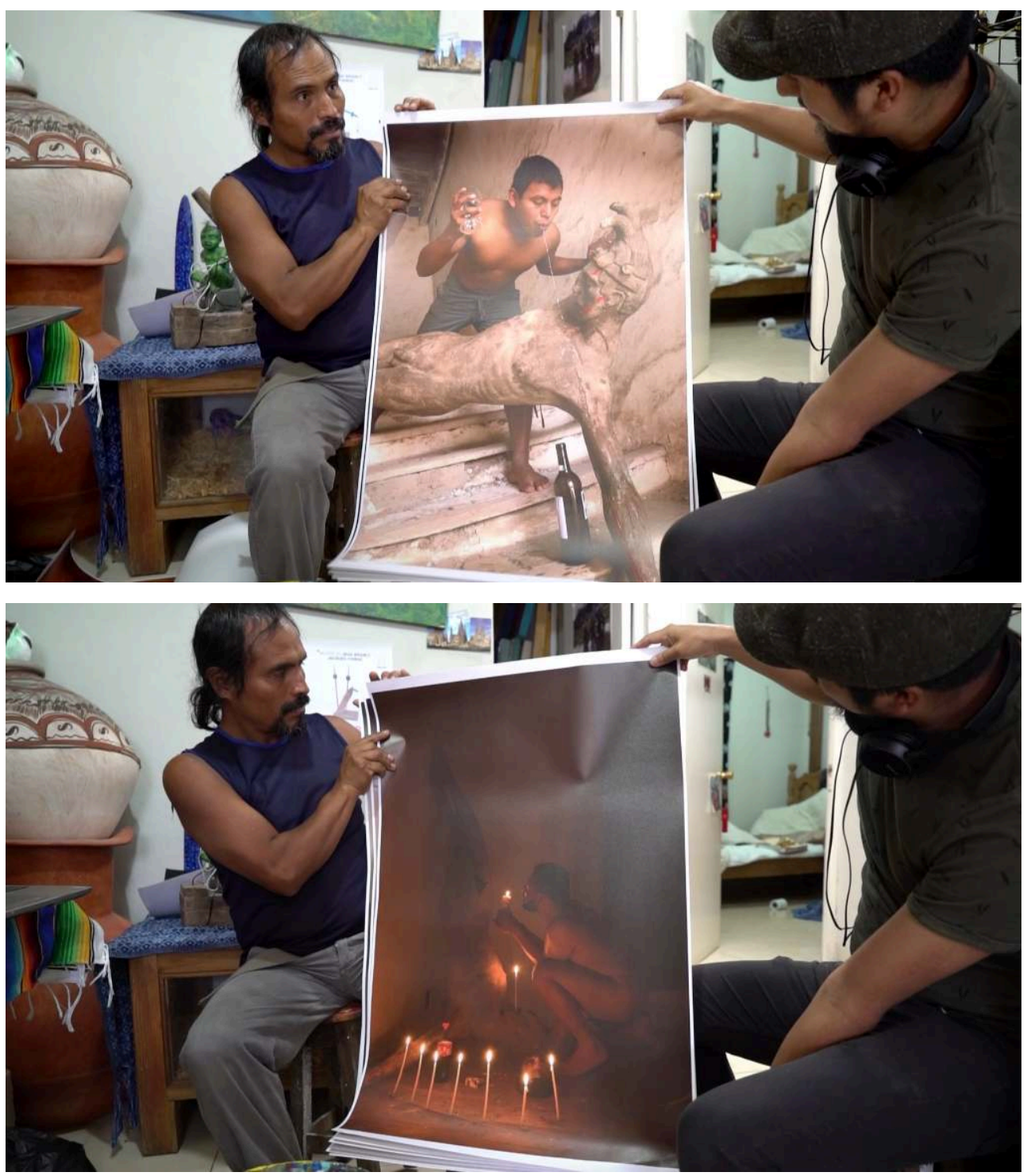


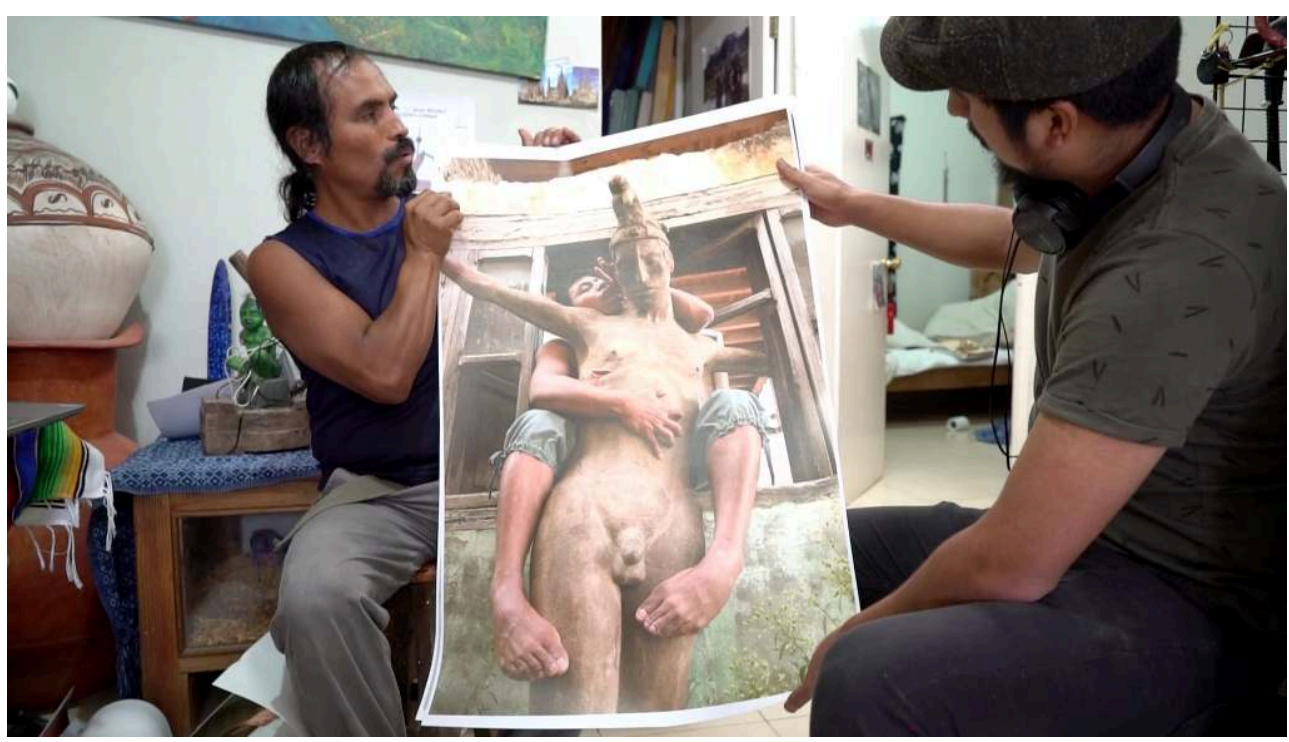

Juan Chawuk (left) and a friend of him show me prints of Juan's photographic work, while Juan talks about each image.

Photos by Thomas John 2017.

In the photos above and below, one can see a sculpture of the ancient Mayan king Pakal, sculpted with a synthetic material by Juan. Pakal is represented in a posture reminiscent in iconographical terms of the crucified Jesus Christ. He has crossed feet, and there is blood on his bent head, on his legs, on his outstretched arms, and on his chest. Unlike Jesus, Pakal is represented completely naked. Juan invited people to be photographed while performing an encounter with his sculpture of Pakal. People from ethnic communities and Ladinos were likewise participants. He asked them to perform an interaction with the sculpture. Moreover, he took "Pakal" to public places in different cities and towns in Chiapas to cause spontaneous reactions and situations of people encountering his statue. This produced very different reactions and interesting conversations, including negative responses. Some people had been feeling highly annoyed by his statue, especially since he exhibited it several times at public squares in front of churches. Juan showed me around 20 large prints of his photos he took of people interacting with his sculpture. The photo show was exhibited in Mexico and the USA in 2016.

K'inich Janaab Pakal I, also known as Pakal the Great, was the most important ruler of the Mayan city-state Palenque in Chiapas ${ }^{4}$. Nowadays, especially people of Mayan descent like Xun and Juan who reappreciate and reaffirm their cultural roots and their languages, take Pakal as a meaningful symbol of veneration, cultural heritage, and pride. 
Figures 17, 18, 19, 20: People in interaction with "Pakal"
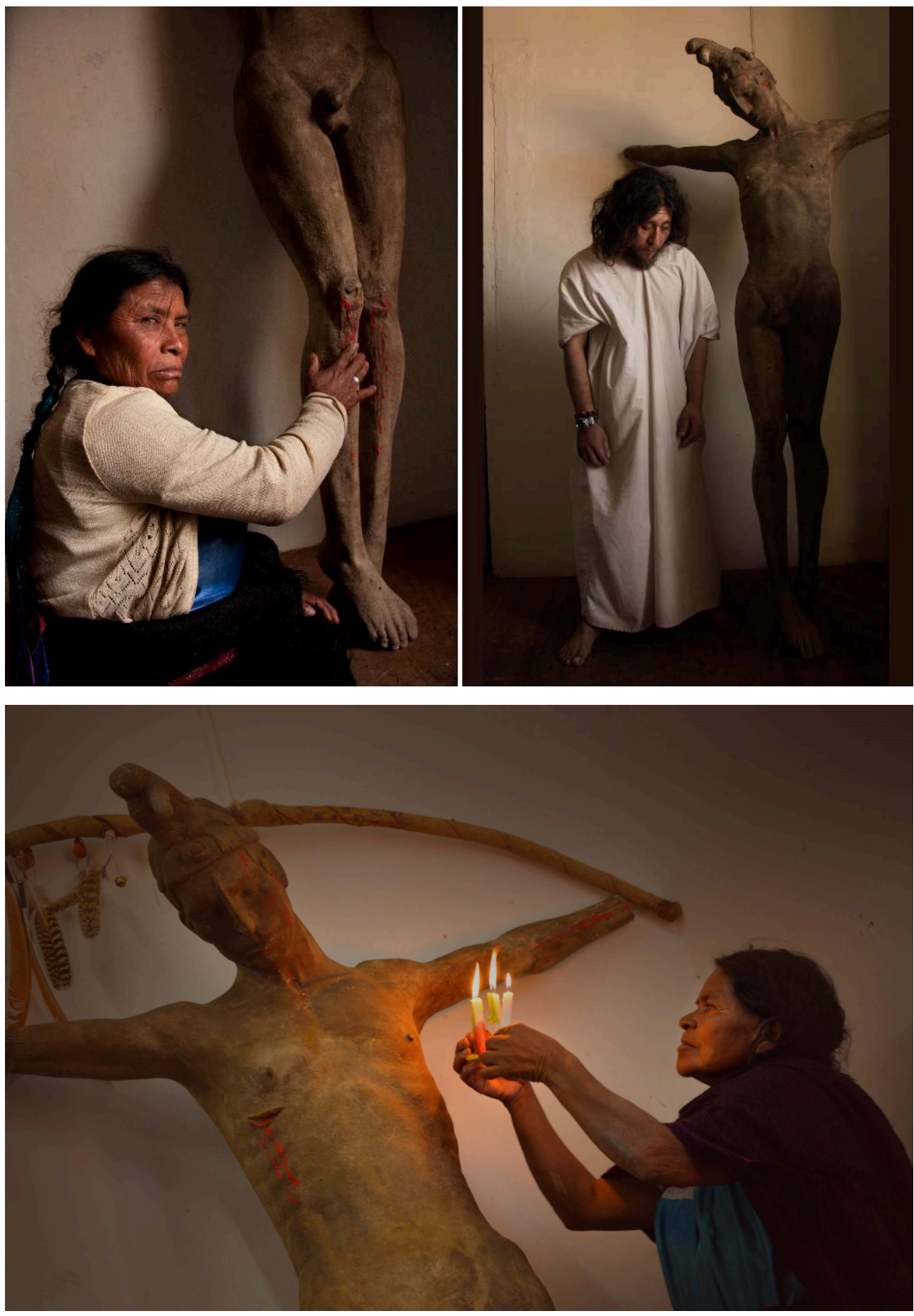


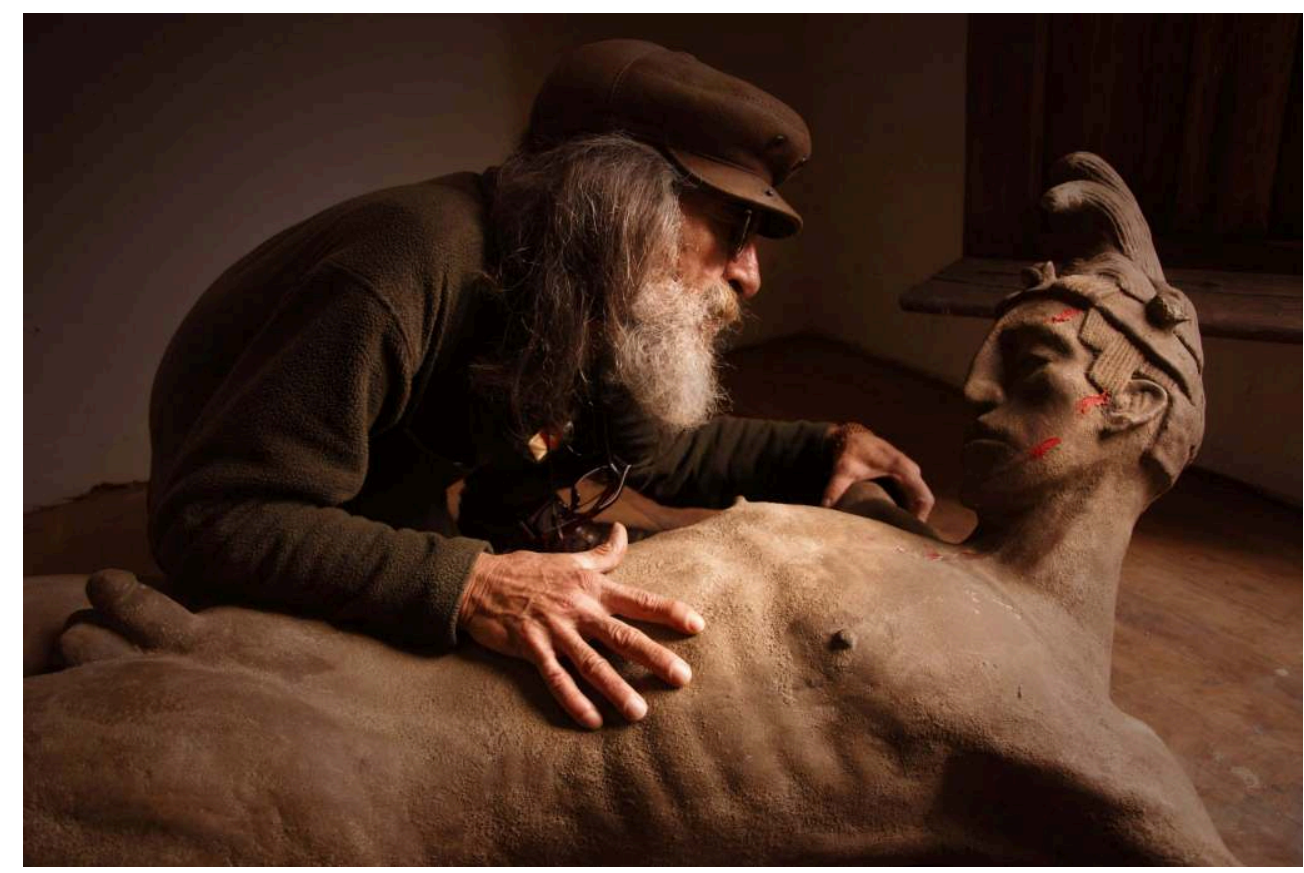

Photo by Juan Chawuk 2016.

41 The sculpture of Pakal represents the local syncretism between Christianity and preColumbian religions, but it also represents how icons have been imposed or forcedly replaced. On the other hand, one could also interpret the sculpture the other way around: Juan imposed on Jesus' body the head and the face of Pakal, which could be a symbolic act of challenging or reversing colonial, religious, and cultural imperialism. More than that, the sculpture is naked, and Juan sculpted its penis slightly erect on purpose, as he told me. That is a provocation that might cause diverse feelings, interpretations, and reactions.

Is the Jesus-like body sexually aroused by having Pakal's head on its body? Juan does not provide very clear interpretations but told me that he wants to provoke feelings and reflections, without imposing too many explanations. Figure 18 has been described by Juan in an interview with me as a photo of "Juana and her angry reluctant gaze caused by touching the evidence of submission and imposition", figure 19 he described as "a Lacandon ${ }^{5}$ in ironic reflection about the imposed icons", figure 20 he described as "Maruch, a healer woman and artist illuminates Pakal with her culture", and figure 21 he pictured as "a person speaking to Pakal intimately trying to find out occult parts of history". ${ }^{6}$

Most of my interlocutors, and Juan as well, criticise the imposition of Christianity on the one hand, but they stress at the same time, that Mayan religious practices, believes, and traditions are still practiced next to Christian practices, and that pre-Colombian traditions and spirituality syncretized with Christianity. The work of the sculpture "Pakal" and the photo series shows not only how icons have been imposed, and vice versa, by giving a sculpture of Jesus the face of Pakal, this work expresses Pakal as a powerful symbol that Mayan spirituality and religious practices are still at work. Maruch charges the sculpture with her culture (figure 19), as Juan described this photo to me. In figure 14 we can see a healing ceremony to heal children, as Juan explained to me, and he said that one could interpret this as Pakal being healed here symbolically from the historical and political negation he suffered though colonialism and the 
suppression of local religions by Christianity. Figure 15 shows an improvisation of a Mayan ritual, however, the sculpture of Pakal is turned upside down, which clearly evokes the idea of a Christian crucifix turned upside down. There is a bottle of Coca Cola and there are candles next to the "Pakal". It is common in Chiapas that foods, candles, tobacco, and drinks are offered to domestic altars or sacred places, to the dead, and to a spiritual being or god, such as to the soil, or to the Lords of the hills, but also to Christian icons, which is a form of local syncretism. The same person who is portrayed in figure 18 as "a Lacandon in ironic reflection about the imposed icons", which provokes a rather critical notion, also enacted harmonious moments with Pakal, which Juan photographed and showed me, too. The same person is also hugging the sculpture and Juan said to me, that the person connects to his ancestors here while hugging "Pakal", and he is photographed together with his wife, too, while they take Pakal between each other and look at him with pleasure and admiration.

Hence, Juan's sculpture of Pakal and the photographic project may be seen as an act of an "insurrection of subjugated knowledges" (Aparicio and Blaser 2008) leading to ethnic empowerment and a practice of decolonisation, but contrarily and at the same time, as a way of questioning and pointing to the sustaining impacts that coloniality has on people and their social, religious and political ideologies. The project provokes a transcultural understanding of the complexity and historical entanglements of local identities and feelings of belonging. In his own words, Juan described his project as follows:

"I tried to photograph perspectives from which the sculpture is always a central protagonist in the image, because it forms part of the syncretism and the domination that exists here in Chiapas. Pakal evokes the imposed icon, which was imposed by the Conquista, and by a conqueror who brought with him an emblem [Jesus or the crucifix], which we consider a symbol of peace and love, but behind his back he had a sword to turn the conquered people into slaves. Historically speaking, this story is not a very romantic one; that was a very violent time. To take up this iconographic posture, and to combine it with Pakal, that might take us to different thoughts and emotions about who we are today. [...] I like the way in which all of the persons demonstrate admiration or disrespect to the sculpture" (Interview with Juan 2017, author's translation).

Juan challenges ways of knowing and seeing, which we might again conceive as a specific form o "epistemic disobedience". Through his work he expresses disobedience to the dominant national grant narrative and political ideology, that proposes the final assimilation of the supposedly "backward" and "ignorant" ethnic communities, their languages and cultures to the "modern" Mestizo society, conceptualized and idealized as "la raza cósmica" ("the cosmic race") of mixed blood (López Caballero 2009, 2016, Leyva Solano 2005).

After showing me the prints of his project of Pakal and giving some thoughts about each photo, Juan took out the regional newspaper from the district of Comitán, another ex-colonial city in Chiapas. There was an article in the newspaper about Juan exhibiting "Pakal" at the square in front of the cathedral. The headline of the article stated: "Expresión Artísta" incomada a la población (Engl. "artistic expression" discomforts the citizens). To express irony, the words "artistic expression" have been put in quotation marks, as if this is not really a true art expression. Juan read the whole article out loud, while I continued videotaping. The author of the article describes only negative reactions and comments of people, also quoting negative reactions, and describes, that the "indigenous" guy turned up with three European foreigners who have possibly 
manipulated him to do that intervention in public. "Certainly, the Indígena who brought the sculpture was influenced by other cultures, who try to creep into the church. Maybe even he himself does not know at all what he is doing, but he is probably influenced by foreigners"'. The author then mentions other art events happening lately at the square "which were very pleasant", like a concert of musicians from Peru, a performance of clowns, and religious, artistic, and musical performances. The author thanks the local police forces, who reacted very well and interrupted Juan's intervention, took him to the police station and removed the portable sculpture.

Juan told me that there were also many positive reactions, especially by local students, and that there were many people interested in his "artistic expression", which the newspaper does not mention. But what bothers him most is not that the police interrupted his performance. He was aware and expected that his work might cause angry reactions in "Catholic Mexico", he told me. What really makes him feel uneasy is that the newspaper reports about him as an Indigena being manipulated by foreigners, and as somebody naive who does not know himself what he is doing. In fact, the foreigners had witnessed a previous performance by him and had asked him if they could accompany him to film him doing one of his public interventions, and he had allowed them to do so.

That is obviously a very colonial and hegemonic perspective on Juan by the newspaper. This demonstrates very well the contested affective relation between the Ladino and the indigenous societies in Mexico. Ironically, or maybe "logically" in its own terms, the newspaper, which is a medium of the Ladino society, reacts with a colonial attitude to Juan's attempt to do a decolonising intervention in public. He is being stereotyped as naive and manipulated.

How does that impact on the affective atmosphere that people like Juan perceive and experience, while moving in such urban spaces? Following affect studies, affective relations influence how people relate emotionally to places, things, institutions, spaces, discourses, behaviours, expressions, and other people. Such an affective relation is never a fixed one, but there are dynamic transformations (Slaby and Röttger-Rössler 2018, John 2016). Art practices, the dissemination of art and media representations, and related interventions in public, such as those by Juan, are reactions and are themselves a counterpart within such affective atmospheres, influencing the local field of tension between racialisation, coloniality and decoloniality. How media and art can play an affective role to shape the feelings and practices of social and political collectives as "affective societies" has been conceptualized especially through the concept of "affective economies". "Whereas the term economy refers to the totality of production, distribution, and consumption in a society, the concept of affective economy focuses more narrowly on the exchange and circulation of affects through media“ (Lehmann, Roth and Schankweiler 2019, Ahmed 2004). 
Figure 21: Juan reads out load from the newspaper Comitán Hoy

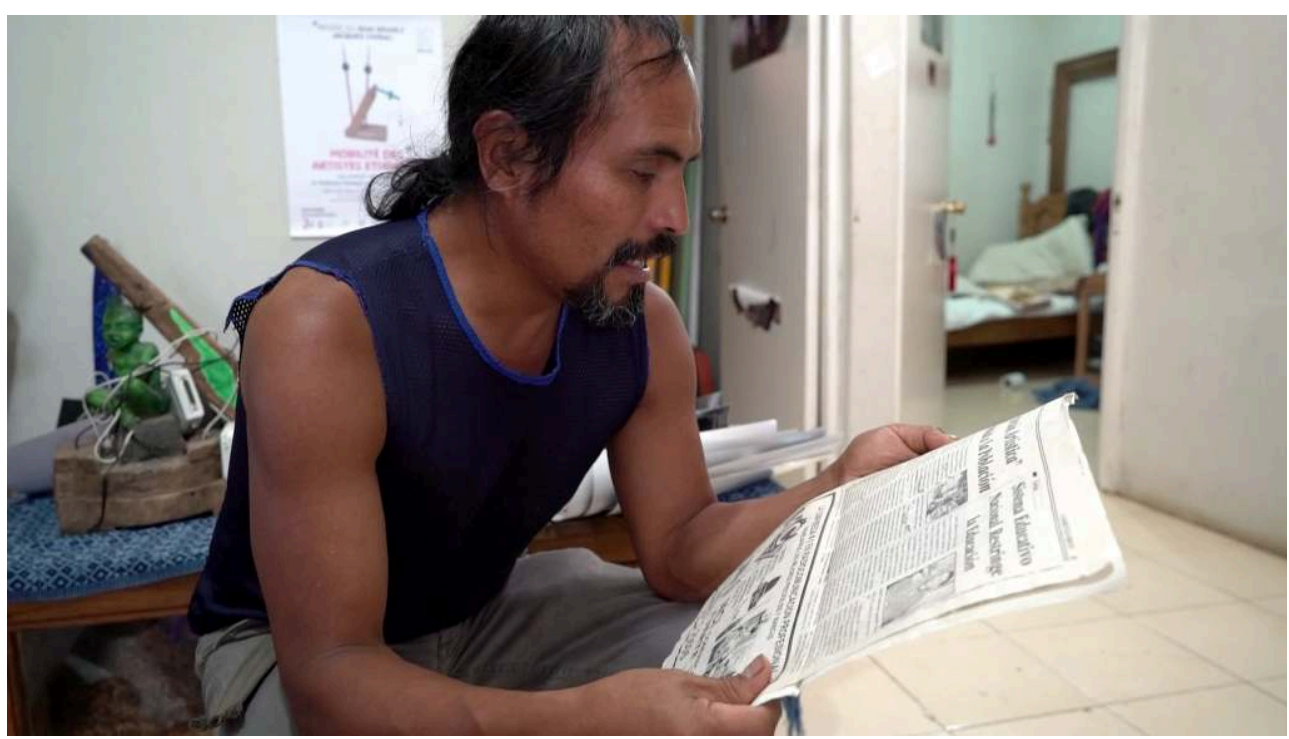

Still photo from my fieldwork video recordings 2017.

CREDIT=Photo by Thomas John 2017.

\section{Images and (De-)Coloniality in Context}

taking photos was a very central element of our role-play, it might be relevant to explain that local people from ethnic communities in Chiapas have been for decades' popular subjects for photos and videos which national and international tourists, producers of documentary film and photography, or anthropologists take of them. One can buy postcards, photos, or photo books of "indigenous" people in the centre of San Cristóbal de las Casas at many shops. However, many people have issues with being subjects of photos taken by strangers. Not everyone asks the locals before they take a photo or a video, and also if one asked, or even paid the protagonist to take a photo, there still remains the strange relation between those who are subjects of a photo and those who take a photo (Walter 2018: 52) . $^{8}$

51 I witnessed at many times tourists obviously taking photos with telephoto lenses of people from far away, but apparently zooming in extremely close. Some communities, such as the Tseltal community Tenejapa, require a fee from tourists or anthropologists to take images at local community feasts or rituals. Other communities, such as San Juan Chamula, totally banned taking photos or video of feasts and sacred events. There, one gets really into trouble with the local authorities or angry people for taking photos. or the selfies of the role-play photoshoot, is something that reminds local people (or anybody familiar with the context) of the feeling and the situation of the above described image production on the part of tourists, journalists etc. and its representational politics.

Next to national and international tourists, anthropologists, or documentary journalists, there are national popular media, such as television and its news or its telenovelas, which depict "indigenous" people in a certain and often stereotyping manner9. López Caballero (2016) quotes for example newspaper reports, such as a 
report about a road blockade by "indigenous farmers" or a news reporting that eight Indígenas prepare for their postgraduate study courses at a university XY. Why does it matter that there are eight Indigenas among the postgraduates? What does that information imply? Does that imply that these eight persons are very exceptional to reach postgraduate studies, even though they are indigenous? What do these eight people have in common? López Caballero analyses such media representation and its rhetoric as having a homogenising effect, putting people under one category, no matter who they really are.

As I have learned through conversations, many local people in Chiapas are highly suspicious about anthropologists and "western" foreigners in general, because there have been very many of them and they have taken so much material and information from the region, its people and their cultures, but have returned very little in someway or another to the communities. People also refer especially to images and films "being taken (away) from them". Due to its multi-ethnic and ethno-lingual diversity, Chiapas and its population has been a hotspot of historical, linguistic, archaeological and anthropological investigations. Numerous researchers and among them many anthropologists came through the long-term Harvard Chiapas Project (1957-80) to the region.

Also, people born in the late period of this project, after it, or nowadays know about it. It became part of the knowledge of a collective memory in communities, that at some point many generations of anthropologists came through the Harvard Chiapas Project and recorded many interviews, audios, film and photo materials, but communities have never seen those afterwards and their information has been taken away to libraries and archives of the USA - and they are right. The anthropologists and historians Jan Rus and Diane Rus, who came initially to Chiapas on behalf of the Harvard Chiapas Project are two of the few exceptions ${ }^{10}$. By talking to me critically about the anthropologists in Chiapas, people either implicitly critiqued me, too, for being an anthropologist in the region, or wanted to warn me, and remind me to do a better job. Thereby they also acknowledged, I suppose, that they know very well what an anthropologist is and does.

Filmmakers, photographers, and visual anthropologists were also critiqued very harshly by scholars such as Nichols (1994), Minh-ha (1991), and Barriendos (2011). The latter elaborates on "la colonialidad del ver" (Engl. "the colonial gaze") specifically for the Latin American context. Minh-ha and Nichols argued that ethnographic filmmakers are colonial and outdated, since there are already enough of those "Others", who produce their own media about themselves, often referred to in the literature as "indigenous media" or Third Cinema, a concept that derives from Latin America (Ginsberg 1995, Dowell 2013, Raheja 2007, Schiwy 2008, Schiwy and Wammack Weber 2017 and many others). I find these critiques and especially Minh-ha's very relevant, however I do not think that this means we cannot make any representation of other people in a postcolonial setting, but we certainly have to do things differently and critically. In my opinion, a transcultural collaboration in the sense of a joint participatory and partnership media production (Ginsberg 1995, Walter 2018) might be one option, even though not an imperative for every work and work context. 


\section{Final Reflections and Summary}

57 I analysed Xun Betan's museum selfie and gave then insights into our photoshoot and to another photographic and sculptural work ("Pakal") by Juan Chawuk. The photos, the role-play and Juan's interventions with "Pakal" in public all evoke and question thoughts and feelings about the representational politics of images. This might trigger different affective notions and reflections of (de-)coloniality, and point to the matter on which colonial history continuously impacts. However, at the same time the works of the local artists stimulate "decolonial thinking" (Mignolo 2007, 2013). I also spoke about the perception and the experiences of local people with media, photography, anthropologists and tourists, and how misrepresentation, patronizing and hegemonic relationships continue to be mediated through images and other media. Images, including why or how images are produced and by whom, are an issue. The local media and art movement reacts and positions itself in that context.

Initially, I also presented the ethnographic context of local media producers in the very particular setting of the countryside metropolis San Cristóbal de las Casas, to help the readers to understand my case-study linked to the specific multi-ethnic circumstance and its racialized divide. Later, I related also some experiences I had with Juan and Xun in public, and gave some insights into Xun's experiences of being discriminated against in his childhood and youth by Ladino classmates and teachers, which had led himself to discriminate even against his own mother and to feel ashamed of himself. These matters show how deeply racism is evident in day-to-day life, and that therefore, our photoshoot and the other photographic works presented in this article, are articulations of an epistemical disobedience to common knowledge about and prevalent prejudices against indigenous people.

The experiences with Juan in the restaurant, and with Xun at the local market, show that while we might have just enacted and played a grotesque role reversal for the photoshoot to perform a notion of colonial history, that this history is continuing to affect our relationships today. Even though I could claim that I consider Xun or Juan as persons with whom I am in a horizonal relationship, and even though Xun an Juan might say that 'Thomas, even though he is an anthropologist, is all right', it can still happen that we are suddenly put in a top-down power relation by people. The reactions of Xun and Juan in these situations go hand in hand with their artistic works. They produce decolonial moments through their art but also by their practices and their reactions to situations of racism. In this way, I believe, they produce decolonial affect which they disseminate through media representations and media practices to affect themselves and others with a disobedient mood of cultural resistance and belonging, and reappreciation of cultural ethnic diversity. 


\section{BIBLIOGRAPHY}

Acker, Marion, Edda Heyken, Omar Kasmani, Dominik Mattes. 2019. Belonging. In Affective Societies: Key Concepts. Jan Slaby and Christian von Scheve, eds. Pp. 300-309. New York, London: Routledge.

Ahmed, Sara. 2004. The Cultural Politics of Emotion. London: Routledge.

Aparicio, Juan Ricardo and Mario Blaser. 2008. The 'Lettered City' and the Insurrection of Subjugated Knowledges in Latin America. Anthropological Quarterly 81(1): 59-94.

Barriendos, Joaquín. 2011. La colonialidad del ver. Hacia un nuevo diálogo visual interepistémico. Nómadas, no. 35: 13-29.

Bens, Jonas, Aletta Diefenbach and Thomas John, et al. 2019. The Politics of Affective Societies. An Interdisciplinary Essay. Bielefeld: transcript.

Berg, Ulla and Ana Ramos-Zayas. 2015. Racializing Affect: A Theoretical Proposition. Current Anthropology, 56(5): 654-677.

Bolter, Jay D. and Richard Grusin. 2000. Remediation: Understanding New Media. Cambridge, MA: MIT Press.

Couldry, Nick. 2010. Theorising Media as Practice. In Theorising Media and Practice. Birgit Bräuchler and John Postill, eds. Pp. 35-54. New York and Oxford: Berghan Books.

Degner, Jennifer. 2016. Thick Photography. Journal of Material Culture. 21(1): 111-132.

Dowell Kristin L. 2013. Sovereign Screens. Aboriginal Media on the Canadian West Coast. Lincoln: University of Nebraska Press.

Ginsburg, Faye. 1995. The Parallax Effect: The Impact of Aboriginal Media on Ethnographic Film. Visual Anthropology Review 11(2): 64-76.

Gregg, Melissa and Gregory J. Seigworth, eds. 2009. The Affect Theory Reader. Durham, NC: Duke University Press.

John, Thomas. 2016. La producción de pertenencia afectiva por parte del movimiento de los medios indígenas en Chiapas. In La producción afectiva de comunidad: los medios audiovisuales en el context transnacional México-EE.UU. Ingrid Kummels, ed. Pp. 317-356. Berlin: Tranvia.

Kummels, Ingrid and Thomas John. 2019. Investigating Affective Media Practices in a Transnational Setting. In Analyzing Affective Societies. Methods and Methodologies. Antje Kahl, ed. Pp. 183-198. New York: Routledge

Lehmann, Hauke, Hans Roth and Kerstin Schankweiler. 2019. Affective Economies. In Affective Societies. Key Concepts. Jan Slaby and Christian von Scheve, eds. Pp. 140-151. London: Routledge. Leyva Solano, Xochitl. 2005. Indigenismo, Indianismo and Ethnic Citizenship in Chiapas. The Journal of Peasant Studies 32(3 \& 4): 555-583.

López Caballero, Paula. 2009. The Effect of Othering. The Historical Dialectic of Local Natioal Identity Among the Originaries, 1950-2000. Anthropological Theory 9(2): 171-187. Sage Publications. López Caballero, Paula. 2016. Pistas para pensar la indigeneidad en México. Interdisciplina 4(9): 9-27.

MacDougall, David. 1998. Transcultural Cinema. Princeton, NJ: Princeton University Press. 
Mignolo, Walter. 2007. Delinking. Cultural Studies. 21(2-3): 449-514.

Mignolo, Walter. 2010. Epistemic Disobedience. Rhetoric of Modernity, Logic of Coloniality and Decolonial Grammar. Buenos Aires: Ediciones Del Signo.

Mignolo, Walter. 2013. Coloniality of Power and De-Colonial Thinking. In: Globalization and the Decolonial Option. Walter Mignolo and Arturo Escobar, eds. Pp. 1-19. London and New York: Routledge.

Mignolo, Walter and Arturo Escobar, eds. 2013. Globalization and the Decolonial Option. London and New York: Routledge.

Minh-ha, Trinh T. 1991. When the Moon Waxes Red. Representation, Gender and Cultural Politics, London andNew York: Routledge.

Nichols, Bill. 1994. The Ethnographer's Tale. In Visualizing Theory. Selected Essays from V.A.R. 1990-1994. Lucien Taylor, ed. Pp.60-83. New York and London: Routledge.

Poole, Deborah. 1997. Vision, Race, and Modernity: A Visual Economy of the Andean Image World. Princeton Studies in Culture/Power/History. Princeton, NJ: Princeton Paperbacks.

Raheja, Michelle. 2007. Reading Nanook's Smile: Visual Sovereignty, Indigenous Revisions of Ethnography, and Atanarjuat (The Fast Runner). American Quarterly 59(4): 1159-1185.

Rappaport, Joanne. 2008. Beyond Participant Observation. Collaborative Ethnography as Theoretical Innovation. Collaborative Anthropologies 1: 1-31.

Riedel, Friedlind. 2019. Atmosphere. In Affective Societies. Key Concepts. Jan Slaby and Christian von Scheve, eds. Pp. 85-95. New York: Routledge.

Rus, Jan and Gaspar Morquecho Escamilla. 2015. The Urban Indigenous Movement and Elite Accommodation in San Cristóbal, Chiapas, Mexico, 1975-2008: Tenemos que vivir nuestros años / "We have to live our own times". In Enduring Reform, Progressive Activism and Private Sector Responses in Latin America's Democracies. Jeffrey W. Rubin and Vivienne Bennett, eds. Pp. 81-112 Pittsburgh: University Press.

Rus, Jan, Diane L. Rus and Salvador Guzmán Backbalom. 2016. El Taller Tzotzil, 1985-2002: Un projecto coloborativo de investigación y publicación en Los Altos de Chiapas. Tuxtla Gutiérrez: Universidad de Ciencias y Artes de Chiapas. https://www.researchgate.net/publication/

301204117_El_Taller_Tzotzil_1985-2002_Un_proyecto_colaborativo_de_investigacion_y_publicacion_en_Los_Altos_de_Chiapas (accessed 28 October, 2020)

Schiwy, Freya. 2008. Indigenous Media and the End of the Lettered City. Journal of Latin American Cultural Studies 17(1): 23-40.

Schiwy, Freya and Byrt Wammack Weber, eds. 2017. Adjusting the Lens. Community and Collaborative Video in Mexico. Pittsburgh, NJ: University of Pittsburgh Press.

Slaby, Jan and Birgitt Röttger-Rössler. 2018. Introduction: Affect in Relation. In Affect in Relation: Families, Places, Technologies. Essays on Affectivity and Subject Formation in the 21st Century. Birgitt Röttger-Rössler and Jan Slaby, eds. Pp. 1-28. New York: Routledge.

Skoggard, Ian and Alise Waterston. 2015. Toward and Anthropology of Affect and Evocative Ethnography. Anthropology of Consciousness 26(2): 109-120.

Walter, Florian. 2018. On the Road with Maruch: Filming Culture and Collaboration as a Transcultural Partnership Process. Berliner Beiträge zur Ethnologie 44. Berlin: Weißensee Verlag. 


\section{NOTES}

1. My research is informed especially by the affect theoretical context of the Collaborative Research Centre (SFB 1171) Affective Societies: Dynamics of Social Coexistence in Mobile Worlds of the Free University Berlin and the German Research Foundation, where I have worked as a research associate from 2016-2020.

2. I draw on numerous conversations and interviews I conducted with local artists and media producers while spending several periods of fieldwork staying for months to research for my dissertation project in Chiapas.

3. Berg and Ramos-Zayas (2015) theorise the affective relation between "whitened elites" and their counterparts, and analyse how this creates an "affective economy" in which affects are being racialised (Berg, Ulla and Ana Y. Ramos-Zayas 2015). Racializing Affect A Theoretical Proposition, in: Current Anthropology, Volume 56, Number 5, pp. 654-674.

4. Pakal is known for the monumental architecture he had constructed. His tomb was discovered in 1948 and is one of the most important archaeological discoveries in Mexico. He ruled from 615-683 CE which was the time of the famous classic Mayan period when Mayan kings ruled over a large territory.

5. The Lacandonians are a Mayan ethnic society from Chiapas. They are no longer as numerous as the Tsotsil, Tseltal, and Tojolabal in Chiapas. Lacandonians and the Lacandon language are under threat of extinction.

6. The Lacandonians are a Mayan ethnic society from Chiapas. They are no longer as numerous as the Tsotsil, Tseltal, and Tojolabal in Chiapas. Lacandonians and the Lacandon language are under threat of extinction.

7. Quote from the newspaper "Comitán Hoy" (Engl. Comitán Daily). Author's translation from Spanish.

8. See Walter (2018) on local perspectives on photography and taking photos of people in Chiapas.

9. This issue has been expressed through the comments of the filmmaker María Dolores Arias Martínez, too, which I have quoted while contextualizing the local ethnic media movement. (See above.)

10. See for instance Rus, Rus and Gúzman Bakbolom (2016). I met Jan Rus in 2017 when he told me in detail about some of their undertakings. In 2016, Jan Rus, Diane Rus and Salvador Gúzman Bakbolom published their book El Taller Tzotzil, 1985-2002: Un proyecto colaborativo de investigación y publicación en Los Altos de Chiapas which reflects on a long-term project of collaboration and investigation.

\section{ABSTRACTS}

I share in this paper experiences and insights from my fieldwork in a local ethnic artist's and media producer's network in South-Mexico. As an attempt at transcultural collaboration, I took part in a nude photoshoot for a local photographer, as a subject also for his project. We swap and potentially subvert the common procedure, in which (visual) anthropologists produce knowledge and (audio-visual) representations about indigenous people, but not the other way around. Nevertheless, this event contributes also to my fieldwork and to my own ends. I discuss this photoshoot and some other works of the two artists involved, while contextualising this in 
relation to the local ethnographic context of a multi-ethnic society marked by a stark racial division and marginalisation. At the same time, this article draws on some selected perspectives of affect theory in the cultural studies (Gregg and Seigworth 2010, Slaby and Röttger-Rössler 2018, Ahmed 2004), to point out how the debated visual productions articulate and disseminate decolonial affect. Next to other motivations, the local art and media community produces media specially to affect people and to impact the local affective atmosphere, to change an atmosphere of marginalisation and shame into an affirmative mood of cultural diversity, resistance and pride.

Je partage dans cet article les expériences et les idées que j'ai tirées de mon travail sur le terrain dans un réseau local d'artistes indigènes et de producteurs de médias au Sud-Mexique. Dans une tentative de collaboration transculturelle, j'ai pris part à une séance de photos de nus pour un photographe local, comme sujet également de son projet. Nous avons échangé et potentiellement subverti la procédure commune, dans laquelle les anthropologues (visuels) produisent des représentations (audiovisuelles) de la connaissance et de la publicité sur les populations indigènes, mais pas l'inverse. Néanmoins, cet événement contribue également à mon travail sur le terrain et à mes objectifs de recherche. Je discute de cette séance de photos et de quelques autres travaux des deux artistes impliqués, tout en contextualisant cela en référence au cadre ethnographique local d'une société multiethnique marquée par une division raciale et une marginalisation profondes. En même temps, cet article s'appuie sur certaines perspectives de la théorie de l'affect dans les études culturelles (Gregg et Seigworth 2010, Slaby et Röttger-Rössler 2018, Ahmed 2004), pour souligner comment les productions visuelles débattues articulent et diffusent l'affect décolonial. Parallèlement à ces motivations, la communauté artistique et médiatique locale produit des documents spécialement destinés à toucher les gens et à influer sur l'atmosphère affective locale, à transformer un climat de marginalisation et de honte en un climat d'affirmation de la diversité culturelle, de résistance et de fierté.

En este artículo comparto experiencias y conocimientos de mi trabajo de campo sobre una red étnica de artistas y productores locales en el sur de México. En un intento de colaboración transcultural, participé en una sesión de fotos desnudo para un fotógrafo local, convirtiéndome también en sujeto de su proyecto. Intercambiamos y potencialmente subvertimos el procedimiento común, en el que los antropólogos (visuales) producen conocimiento y representaciones (audiovisuales) sobre los pueblos indígenas, y no al revés. Sin embargo, este evento es también una contribución para mi trabajo de campo y para mis propios fines. Discuto esta sesión de fotos y algunas otras obras de los dos artistas involucrados, contextualizando este evento en el contexto etnográfico local, a saber, el de una sociedad multiétnica marcada por una fuerte división racial y por la marginación. Al mismo tiempo, este artículo se basa en algunas perspectivas precisas sobre la teoría del afecto en los estudios culturales (Gregg y Seigworth 2010, Slaby y Röttger-Rössler 2018, Ahmed 2004) para señalar cómo las producciones visuales debatidas articulan y difunden el afecto descolonial. Junto a otras motivaciones, la comunidad de arte y medios local produce medios especialmente para afectar a las personas e impactar la atmósfera afectiva local, y para transformar una atmósfera de marginación y vergüenza en un estado de ánimo afirmativo para la diversidad cultural, resistencia y orgullo. 


\section{INDEX}

Palabras claves: teoría del afecto, atmósfera, prácticas de medios afectivos, medios indígenas, antropología visual y antropología de los media, descolonización, Indigenismo

Keywords: affect theory, affective economy, atmosphere, affective media practices, indigenous media, visual and media anthropology, decolonisation, indigeneity

Mots-clés: théorie des affects, économie affective, atmosphère, pratiques médiatiques affectives, médias indigènes, anthropologie visuelle et des médias, décolonisation, indigénéité

\section{AUTHOR}

\section{THOMAS JOHN}

Freie Universität Berlin and Westfälische Wilhelms-Universität Münster

Thomas John is a visual and media anthropologist. He worked from 2015-2020 as a research associate at Freie Universität Berlin for the Institute for Latin American Studies and the Collaborative Research Centre Affective Societies: Dynamics of Social Coexistence in Mobile Worlds of the German Research Foundation (DFG). He teaches and coordinates the teaching for the MA Visual Anthropology, Media and Documentary Practices (WWU Münster) and teaches filmmaking classes for the Institute of Ethnology (WWU Münster).

thomas.john@fu-berlin.de,t_john03@uni-muenster.de 